UDK 582.632.2:630*233(497.6)

\title{
DROUGHT-RESISTANCE OF VARIOUS PROVENANCES OF BEECH (Fagus sylvatica L.) FROM PARTS OF ITS NATURAL RANGE IN BOSNIA AND HERZEGOVINA
}

\section{Otpornost na sušu različitih provenijencija bukve (Fagus sylvatica $L_{\text {.) }}$ iz dijela prirodnog areala iz Bosne i Hercegovine}

\author{
Sead Ivojević ${ }^{1}$ Ćemal Višnjić ${ }^{1}$, Faruk Mekić ${ }^{1}$
}

\begin{abstract}
This paper covers a study of the drought-resistance of five provenances of beech in its natural range in Bosnia and Herzegovina. Seeds for this study were gathered in the autumn 2007, and their resulting seedlings were grown in 2008 to produce the material used for the drought-resistance tests.

The results of the drought tests and the lethal dose from 50 calculations suggest that there are clear differences in drought-resistance between the provenances tested. Given that the tested provenances are from an area with varying eco-climatic conditions, the probable conclusion is that drought-resistance is hereditary. The results of the study form a sound basis for the selection of seeds which grow to seedlings used to afforest more extreme habitats.
\end{abstract}

Key words: beech, provenance, drought, resistance, LD50.

\section{INTRODUCTION - Uvod}

The preliminary results of the Second Forest Inventory of Bosnia and Herzegovina, the field surveys of which were carried out between 2006 and 2009, reveal that the total area of forest is 3,231,500 ha, of which beech forest accounts for $1,054,600$ ha, or $32.63 \%$. In addition, beech as a forest tree occurs in both coniferous and deciduous woodland in beech and fir forest with spruce, covering an area of 762,800 ha or $23.61 \%$ of the total forested area of Bosnia and Herzegovina. The combined figures of pure and mixed stands of beech reveal that beech as a species is represented in more than half the total forested area of this country.

This suggests that beech is a very important species economically in Bosnia and Herzegovina. In addition, given the area it covers, and the number of communities it constitutes with other important tree species, it is extremely important from the ecological perspective. Beech plays an invaluable part in preserving the

\footnotetext{
${ }^{1}$ Faculty of Forestry, University of Sarajevo
} 
stability of our forest ecosystems and in maintaining forest soils and diversity; hence its well-deserved epithet "mother of the forest."

The morphological and phenological variability of beech was widely studied in Europe in the $20^{\text {th }}$ century. Several varieties of beech were described as long ago as the $17^{\text {th }}$ century: purple beech (Fagus sylvatica var. purpurea), weeping beech (Fagus sylvatica var. pendula), fastigiate beech (Fagus sylvatica var. fastigiata), fern-leaved or cut-leaved beech (Fagus sylvatica var. lacinata), and a low, wide-spreading beech with twisted branches (Fagus sylvatica var. tortuosa). Though these are clearly mutations which are now propagated vegetatively for horticultural use, both regionally and even within stands over a small area beech displays considerable morphological and phenological diversity. The shape of the crown is very variable, depending on the branching, branch insertion, and leaf size and shape (MUSH, 1986; RICHTER, 1990).

The time of bud-burst of early and late flushing beech has been found to differ by as much as two weeks, even within the same stand. These differences are also genetically determined (COMPS ET.AL. 1987a and 1987b). As regards their resistance to extreme habitats, European beech of Calabrian provenance (Italy) is more resistant to frost and flush later than central European beech (VIŠNJIĆ and DOHRENBUSCH, 2004).

In Slovenia, BRINAR (1963) conducted three trials from 29 local provenances and a number of provenances from the Czech Republic and Poland originating from sites at altitudes ranging from 310 to $1360 \mathrm{~m}$. He investigated the phenology of the various provenances, and found that a delay in flushing by one day corresponds to an altitude difference of $122 \mathrm{~m}$.

Since the Balkan peninsula is the refuge habitat of beech, from which it began to spread to northern and western Europe after the ice age, beech in the Balkans is the oldest in its entire range, and is more variable genetically.

\section{MATERIALS AND METHODS - Materijal i metode}

The material used for the study consisted of two-year-old seedlings of five provenances of beech from Bosnia and Herzegovina originating from various ecoclimatic areas and different altitudes, as detailed in Table 1 and Fig. 1.

Table 1. Basic details of the beech provenances studied

Tabela 1. Osnovni podaci o istraživanim provenijencijama bukve

\begin{tabular}{|c|l|l|l|l|}
\hline No. & Provenance & Site & Altitude $(\mathrm{m})$ & Geographical coordinates \\
\hline 1. & Bužim & "Glinica" & $300-350$ & $45^{\circ} 05^{\prime} \mathrm{N}, 16^{\circ} 05^{\prime} \mathrm{E}$ \\
\hline 2. & Bugojno & "Skrta-Nišan" & $600-700$ & $43^{\circ} 50^{\prime} \mathrm{N}, 17^{\circ} 25^{\prime} \mathrm{E}$ \\
\hline 3. & Banja Luka & "Osmača-Tisovac" & $630-780$ & $44^{\circ} 39^{\prime} \mathrm{N}, 17^{\circ} 10^{\prime} \mathrm{E}$ \\
\hline 4. & Posušje & "Bosiljna" & $950-1050$ & $43^{\circ} 28^{\prime} \mathrm{N}, 17^{\circ} 20^{\prime} \mathrm{E}$ \\
\hline 5. & Olovo & "Patkovac" & $950-1050$ & $44^{\circ} 10^{\prime} \mathrm{N}, 18^{\circ} 30^{\prime} \mathrm{E}$ \\
\hline
\end{tabular}




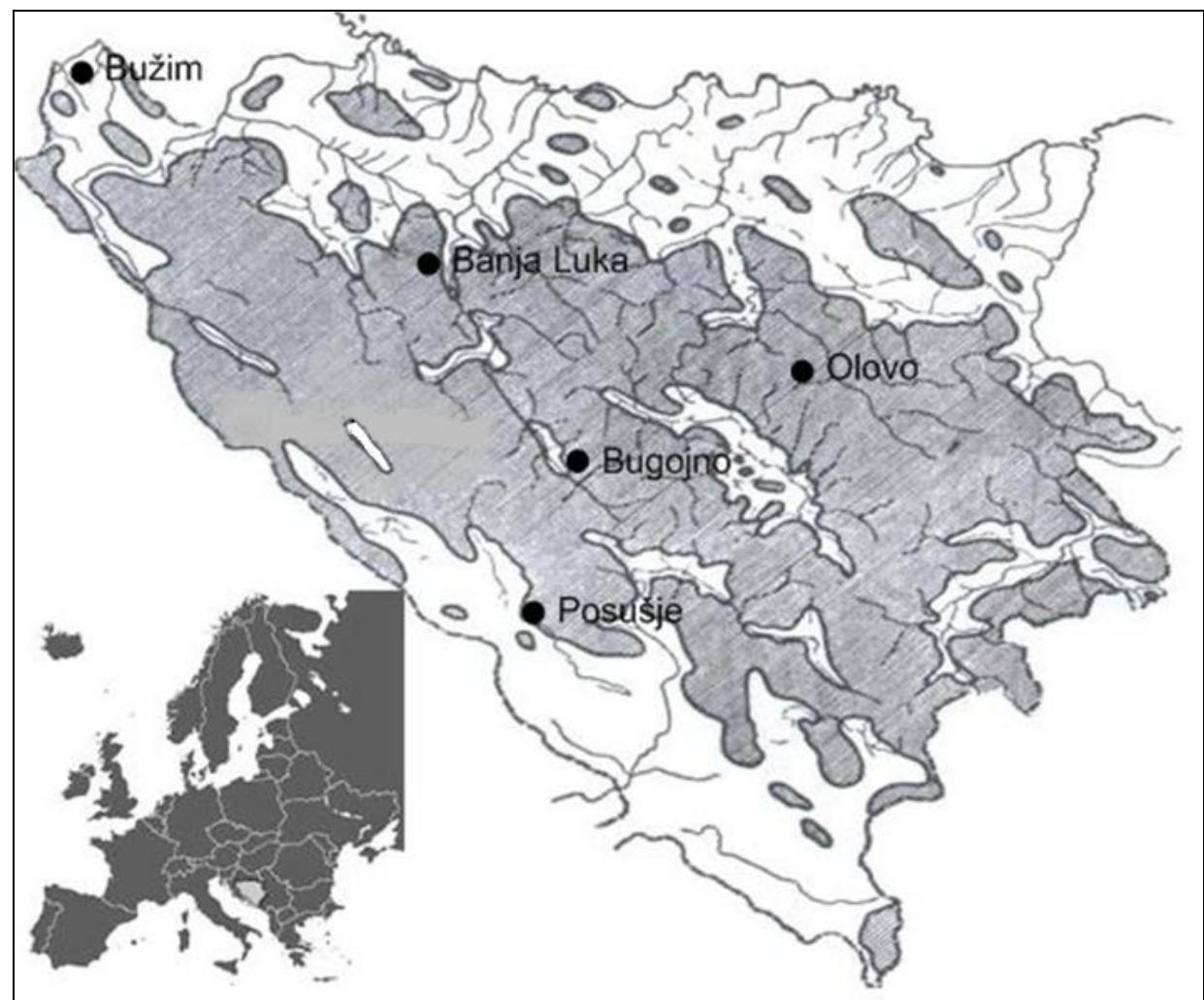

Fig 1. Map showing the distribution of the provenances studied in Bosnia and Herzegovina Slika 1. Prostorni raspored istraživanih provenijencija u Bosni i Hercegovini

To determine the drought-resistance of the various provenances, the seedlings were transferred from the seed bed to containers. The compost into which the seedlings were transplanted was ordinary nursery compost which was homogenized by mixing in a single heap before filling the containers. A crock was placed in each container before adding the compost, to prevent the compost from leaking from the container and to ensure free drainage. After crocking and numbering the containers, the mass of each was determined. Forty-five seedlings from each provenance were transplanted into 2 -litre containers, and another 45 containers were filled with compost without seedlings to serve as controls.

The drought test was conducted in a plastic tunnel in controlled conditions (temperature and precipitation/irrigation).

A physical drought test was carried out on the seedlings of all provenances during summer. The test began on 22 June 2009 by saturating all the containers with seedlings. After the gravitational water had drained away, the actual evapotranspiration was determined by measuring the mass of the containers with seedlings, evaporation alone was determined from the mass of the control containers, 
and the vitality of the plants was assessed. The seedlings were not irrigated during the experiment, which was not time-constrained and was continued until all the test seedlings had dried out completely (VIŠNJIĆ, 2006).

Seedling vitality was assessed on a scale of 1 to 4 , as follows:

4 - Vital seedling (foliage completely green, bark and buds also green)

3 - Average vitality ("slight damage," foliage changing colour but bark and buds unchanged)

2 - Low vitality ("considerable damage," foliage completely yellow, bark and buds still green)

1 - Parched seedling (foliage completely yellow, bark and buds brown)

\section{The LD50 test}

The number of days since the last irrigation, when $50 \%$ of the tested seedlings were dead, marked the boundary limit value of the plants' tolerance to drought and was designated as the lethal dose 50 (LD50). This value may be obtained in two ways, on a graph or by computed interpolation.

In this paper the mathematical model is used to calculate LD50. Statistically, the LD50 value corresponds to the number of days the seedlings had gone without the addition of water, during which $50 \%$ of the seedlings tested had died.

The formula used to calculate LD50 was given by CAVALLI - SFORZA (1972):

$$
\mathrm{m}=\frac{P_{i+1}-P_{i}}{100} * \frac{X_{i+1}+X_{i}}{100}
$$

Where:

$\mathrm{X}_{\mathrm{i}}=\log$ single dose (in our case, the number of days since last irrigation)

$\mathrm{P}_{\mathrm{i}}=$ percentage reaction to single dose

$\mathrm{m}=\log$ of LD50

\section{RESULTS - Rezultati}

The drought test and the selection of the provenances most resistant to drought were conducted on 45 specimens of 2-year-old seedlings of each provenance. Graph 1 shows the average physiological state during the test of the seedlings for the various provenances. 


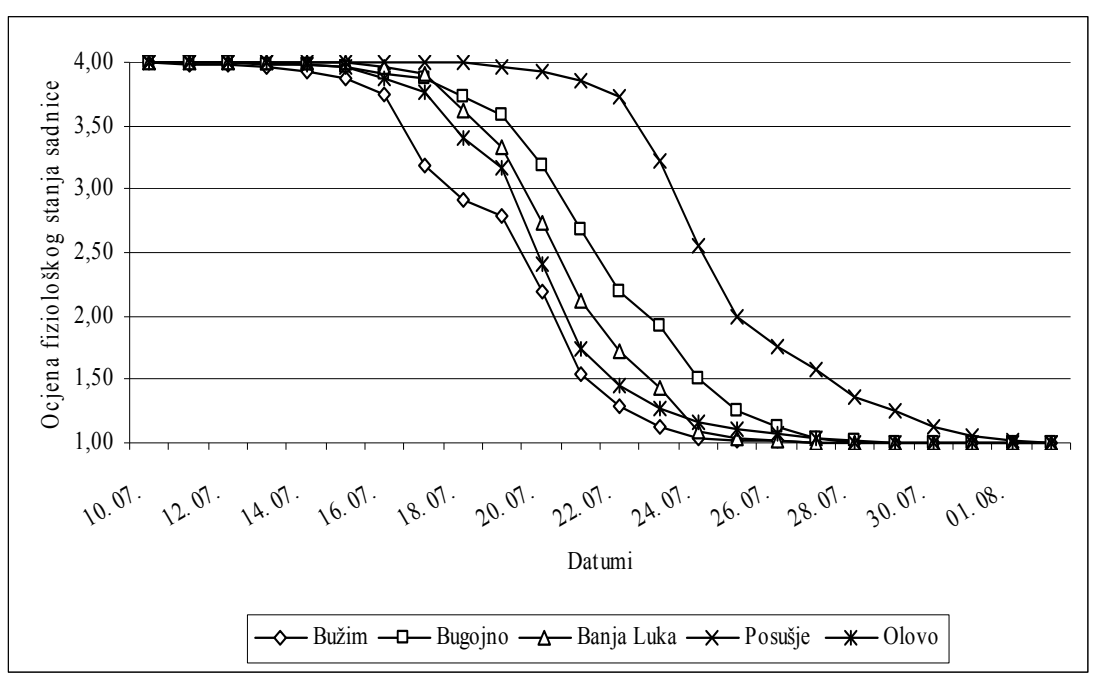

Graph 1. Assessment of physiological state of the seedlings tested for drought-resistance Grafikon 1. Ocijena fiziološkog stanja sadnica testiranih na otpornost na sušu

The curves representing the changes in physiological state of the seedlings of the various provenances show the same trend. However, the lines showing these changes echo the time distances at which the various provenances showed the first reactions to moisture shortfall.

This graph reveals that the seedlings of Bužim provenance were first to display a reaction to moisture shortfall. A day later, seedlings of Olovo, Banja Luka and Bugojno provenance also displayed a reaction, while the seedlings of Posušje provenance displayed the first reaction to moisture shortfall only five days later, in the root system zone.

Towards the end of the drought test, which was not time-constrained, the seedlings from Bužim, Bugojno, Banja Luka and Olovo were completely dried out, while those of Posušje provenance showed the same effect five days after all the others.

The moisture percentage was determined day by day during the drought test by measuring the mass of the containers containing the seedlings, of known water capacity, and the relationship between moisture percentage and the physiological state of the seedlings was determined. The results are shown on the following graph: 


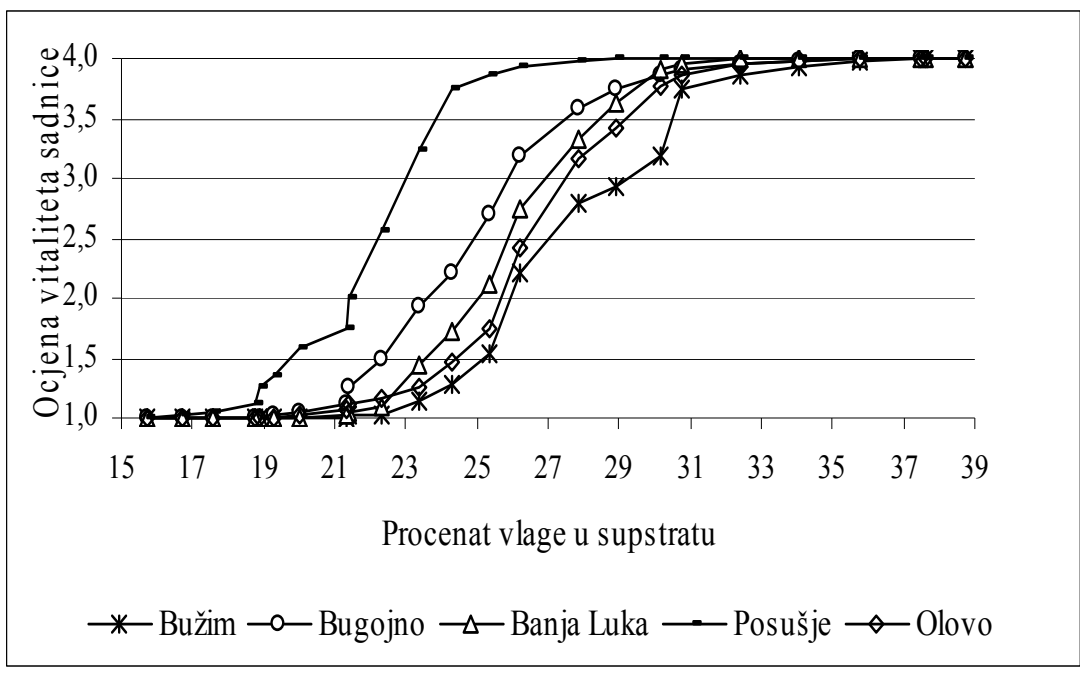

Graph 2. Seedling vitality in relation to the percentage of moisture in the compost, by provenance

Grafikon 2. Vitalitet sadnica u zavisnosti od procenta vlage u supstratu po provenijencijam

This graph shows the changes in physiological state of the seedlings to the point of death in relation to the percentage of moisture in the compost. The seedlings of Bužim provenance were the first to display a reaction to moisture shortfall in the compost, at $35 \%$ of total water capacity of the compost. The last seedlings to display a reaction to moisture shortfall were those of Posušje provenance, at about $29 \%$ moisture content. The loss of vitality and drying out of the seedlings follows a sigmoid curve, as did leaf fall in autumn. All provenances displayed an almost identical progress as the plants dried out in relation to the moisture content of the compost. The curves shifted from a higher to a lower percentage moisture content in terms of the same vitality assessment in the following order: Bužim, Olovo, Banja Luka, Bugojno, with Posušje standing out during the test. At the end of the test all the seedlings from all the provenances tested were completely dried out when the moisture content had fallen to about $19 \%$, whereas the seedlings of Posušje provenance finished the test with a compost moisture content of $16 \%$ of total water capacity of the compost used to conduct the drought test.

\section{LD50 of the seedlings}

The LD50 values for each provenance were calculated from the data yielded by the drought test on two-year-old beech seedlings and the mathematical model for calculating the LD50. These are set out in the following table. 
Table 2. LD 50 by provenance

Tabela 2. LD 50 po provenijencijama

\begin{tabular}{|l|c|}
\hline Provenance & LD50 \\
\hline Posušje & 33.25 \\
\hline Bugojno & 30.18 \\
\hline Banja Luka & 28.65 \\
\hline Olovo & 28.01 \\
\hline Bužim & 27.30 \\
\hline
\end{tabular}

The figures in table 2 represent the number of days without irrigation after which $50 \%$ of the seedlings tested dried out.

The seedlings of provenance in the Bužim area proved to be the most droughtsensitive: 27 days after the last irrigation, $50 \%$ of those tested had dried out. The Olovo and Banja Luka provenances had 50\% of desiccated seedlings after 28 and 29 days respectively without the addition of water. The Bugojno provenance proved to be more drought-resistance than these, with $50 \%$ of seedlings killed by drought after 30 days. The most drought-resistance beech provenance was from the Posušje area: $50 \%$ of the 45 seedlings of this provenance that were exposed to drought in controlled conditions dried out only after 33 days.

\section{DISCUSSION - Diskusija}

Drought may be defined as a complex meteorological phenomenon arising from a long period without precipitation during which increased transpiration results in a moisture shortfall in the root system zone, disrupting the plant's moisture balance (SUPIĆ, 2008).

Not all plants react in the same way to drought. Different individuals of the same species are more or less resistant, able to endure a longer or shorter period without precipitation without significant impact on the life and yield of the plant.

This paper sets out the results of the drought test on beech of various provenances from Bosnia and Herzegovina. The most resistant provenance proved to be from the Posušje area. Seedlings of Posušje provenance were the last to display a reaction to moisture shortfall, the last to pass through the various stages of physiological change, and the last to dry out completely. Furthermore, as shown on graph 2, during the test the seedlings of every other provenance displayed a reaction to moisture shortfall in the compost with an average moisture content of about $35 \%$, whereas those of Posušje provenance displayed a reaction at $29 \%$ compost moisture content. 
The LD50 calculation revealed that $50 \%$ of the Posušje provenance seedlings were dead 33.25 days after the last precipitation (irrigation). In contrast, $50 \%$ of the seedlings of Bužim provenance were dead 27.30 days after the last irrigation.

As noted by MEĐEDOVIĆ ET.AL. (1999), the ability of the plant organism to resist drought conditions is associated with a long period of adaptation to drought. As graph 2 demonstrates, our research identified a significant correlation between LD50 values and total precipitation during the growing season $\left(\mathrm{R}^{2}=0.9748\right)$, which corroborates this assertion. Provenances with a higher total precipitation during the growing season were killed during the drought test more quickly than provenances with a lower total precipitation, which needed longer for $50 \%$ of the specimens to dry out.

Graph 2 (Seedling vitality in relation to the percentage of moisture in the compost, by provenance) clearly shows the differences in vitality of seedlings of different provenances at a given compost moisture content. In this case, the seedlings of provenance from the Posušje area showed greater vitality than the other seedlings at a given compost moisture content, indicating that the Posušje provenance seedlings are better able to exploit the moisture in the compost than are seedlings of other provenances. These results confirm those of CZAJKOVSKI AND BOLTE (2005), which indicate that greater ability to make use of water in the compost points to greater adaptation of the provenance to drought.

From all this, it may be said that over the thousands of years during which beech has been present in this part of the world in different habitats, with different average temperatures and precipitation over the year and during the growing season, have resulted in the adaptation by certain beech provenances to the given circumstances. In addition, one may say that drought-resistance is hereditary, since provenances subjected to a drought test under identical conditions displayed different reactions. The test was also designed to select the provenances studied with a view to the selection of seeds for the propagation of seedlings for planting in dry areas. The rationale for this lies particularly in the economic importance of beech in this country. According to PINTARIĆ (1989), based on the research of other authors (MATIĆ ET.AL., 1969; IZETBEGoviĆ ET.AL., 1986), it is said that "beech should be one of the most important trees for providing the raw material for mechanical and chemical timber processing."

\section{CONCLUSION - Zaključak}

The paper covers the study of five provenances of European beech (Fagus sylvatica L.) from parts of its natural range in Bosnia and Herzegovina. The study covered provenances for the area of Bužim (Glinica), Bugojno (Skrta Nišan), Banja Luka (Osmača-Tisovac), Posušje (Bosiljna) and Olovo (Patkovac). The study was designed to determine the drought-resistance of beech, the results of which lead to the following conclusions: 
- The results of the tests conducted from June to August 2009 demonstrated that seedlings of Posušje provenance are more drought-resistant than all the other provenances of Bosnian beech that were tested.

- The LD50 value for the Posušje provenance was 33 days, the period during which $50 \%$ of the seedlings tested were still alive without the addition of water, making this provenance exceptionally drought-resistant. In the case of the Bužim provenance, however, $50 \%$ of the seedlings tested were alive after only 27 days, making this the most drought-sensitive provenance.

- The difference in LD50 value between the most resistant (Posušje) and the most sensitive (Bužim) provenance was 5 days. Since the test conditions were identical, there is no doubt that different provenances from the natural range in Bosnia and Herzegovina vary in drought-resistance.

\section{REFERENCES - Literatura}

BINAR, M., 1963: O razvojnem ritmu razlicnih bukovih provenienc oziroma ekotipov. Gozd. Vest., 21 (3 - 4): 65 - 90.

Cavalli - Sforza, L., 1972: Biometrie, Grundzüge Biologisch - Medizinischer Statistik.

Comps, B., G. BarRiere D., Mrzeau, Letouzey J., 1987A: La variabilité alloenzymatiqe des hêtraies dans les sous-domains medio- et eu-atlantiqe d'Europe. Can. J. For. Res., 17 (7): 1043 - 1049.

Comps, B., Letouzey J., Savole, J., M., 1987B: Phenologie du couvert arborescent dans une chenaie- hetraie d; Aquitanie. Ann. Sci. for. 44: 153-170.

CZAJKovski, T., Bolte, A., 2005: Unterschiedliche Reaktion deutscher und polnischer Harkünfte der Buche (Fagus sylvatica L.) auf Trockenheit, Allg. Forst-u. J.-Ztg., 177. Jg., 2. Göttingen.

Matić, V., Drinić, P., Stefanović, V., ĆIRIĆ, M., 1971: Stanje šuma u SR Bosni i Hercegovini prema inventuri šuma na velikim površinama u 1964. - 1968. godini, Sarajevo.

MeĐedović, S., Ferhatović, Dž., ČauŠEvić, A., 1999: Fiziologija biljaka - praktikum, Filozofski fakultet Univerziteta u Tuzli, Tuzla, str. 157.

MUSH, H. J. 1986: Variability, provenance research, breeding, vegetative propagation, and gene conservation of beech. IUFRO Cong. Ljubljana, Div. I, Vol. II: 700-702.

PINTARIĆ, K., 1989: Kako sačuvati klijavost sjemena bukve za više godina, Šumarstvo I prerada drveta, svestka $4-6$, str. $113-116$.

RICHTER, J., 1990: Kronentypen bei der Rotbuche, Allg. Forst- u Jagdztg. 161: 11-14.

SuPIĆ, D., 2008: Pojam suše, Izvještaj, Hidrometeorološki zavod RS, Agrarni informacioni centar - AIC. 
VIŠNJIĆ, Ć., 2006: Aufforstung von sommertrockenen Standorten mit heimischen Baumarten in Bosnien. Dissertation zur Erlangung des Doktorgrades der Fakultät für Forstwissenschaft und Waldökologie der Georg-August.Universität Göttingen.

VIŠNJIĆ, Ć., Dohrenbusch, A., 2004: Frostresistenz und Phänolgie europäischer Buchenprovenienzen (Fagus sylvatica L.), Allg. Forst-u. J.- Ztg., Jg. 175, Nr. 6, pp. $101-108$.

\section{SAŽETAK}

Rad obuhvata istraživanje otpornosti na sušu pet provenijencija bukve iz dijela prirodnog areala sa prostora Bosne i Hercegovine. Sjemenski materijal za ova istraživanja sakupljen je u jesen 2007. godine iz kojeg je, naredne 2008. godine, proizveden sadni materijal na kojem je vršeno testiranje otpornosti.

$\mathrm{Na}$ osnovu rezultata testa na sušu i izračunatih „letal dosis 50 “, može se zaključiti da su razlike u otpornosti na sušu među istraživanim provenijencijama evidentne. S obzirom na to da istraživane provenijencije potiču iz područja u kojima vladaju različiti eko-klimatski uvjeti, navodi na zaključak da je osobina otpornosti na sušu nasljadna. Rezultati ovih istraživanja predstavljaju dobar osnov za selekciju sjemenskog materijala iz kojeg ce se u budućnosti proizvoditi sadni materijal za pošumljavanje ekstremnijih staništa. 